\title{
The Need for Introduction of Sharia Microfinance Program in the Gambia
}

\author{
Saikou Gassama ${ }^{1}$, Hamidah $^{2}$, Erina Sudaryati ${ }^{3}$ \\ 1,2,3Faculty Economics and Business, Universitas Airlangga, Indonesia \\ Email: saikou.gassama-2019@feb.unair.ac.id, hamidah@feb.unair.ac.id, erina.sudaryati@feb.unair.ac.id
}

\section{Abstract:}

The Gambia is a 95 percent Muslim country that is located in the western part of Africa. The population of the country is around $2.5 \mathrm{~m}$. The Gambia is largely dependent on Agriculture, tax, tourism, and foreign aid and is ranked 178, in the Human Development Index 2019, the Gambia is classified as a country with medium human development. The paper used the literature review method. Currently, there is various microfinance program that has been existing for years, but none of them are having Islamic microfinance loan products until recently when two are lunched, as a result, some did not take their loans and even those who take it is hard to change their lives because it is purely for profit-making and also the higher interest rate for some of them. Islamic Microfinance would be the best development instrument for the population of Gambia. The microfinance institutions in The Gambia are very well expanded, they are the main source of credit to the Gambian population both rural and urban. Therefore it will be very important if microfinance institutions in the Gambia can introduce sharia microfinance. The objective of this paper is to suggest ways to introduce sharia microfinance in The Gambia and the benefits of sharia microfinance. The results of this study find out that Islamic microfinance is a viable loan product that can work in the Gambia, there are various kinds of Islamic microfinance products that can work for the poor in the Gambia, such as farmers, gardeners, and market vendors or SMEs. And Islamic microfinance could be the best way of eradicating poverty in the Gambia, since it is not based on the predetermined interest rate and have various suitable loan schemes, if well implemented can change lives.

Keywords:

microfinance; sharia; introduction; opportunity; the Gambia

\section{Introduction}

Microfinance began in the 16th century and it is claimed that raising the living conditions of the poor and women is efficient and beneficial by allowing them to obtain the financial services provided by commercial banks and relieve their hunger and poverty (Hassan et al. 2013). The critical debate in terms of the industry's target is the microcredit industry as the mechanism to eradicate poverty. Microfinance's primary goal is to alleviate luxury-related poverty, hunger, and need. Microfinance is an instrument that in many countries is involved in implementing social and economic change. By identifying how microfinance directs its focus towards development, can the relationship between microfinance and development be evaluated? The main objective of both microfinance and development are to eradicate or reduce poverty by providing access to finance and other valuable human needs, such as food, health, shelter, by directly approaching the client's understanding and business development agendas for a better life (Aslam 2016).

Microfinance, as has been argued and confirmed by researchers such as Jaffar and Musa (2014), Gertler, et al., 2009), and Park and Ren (2001), is an effective tool to alleviate 


\section{Economit Journal: Scientific Journal of Accountancy, Management and Finance ISSN: 2775-5827 (Online), 2775-5819 (Print)}

Vol. 1, No. 3, August 2021, Page: 153-164

Email: economitjournal@gmail.com

poverty. Many microfinance projects have been successful, including Grameen Bank in Bangladesh, Bank Rakyat Indonesia in Indonesia, Amanah Ikhtiar Malaysia (AIM) in Malaysia, the Center for Agriculture and Rural Development (CARD) in the Philippines, the International Foundation for Community Assistance (FINCA) and ACCION in Latin America, can be seen in this. Considering this widespread success, to reach the Millennium Development Goal to reduce the number of people living in poverty by half by 2015, the United Nations has included microfinance among its resources. The Islamic financial sector is still in its growing stage, and there is no much literature available on the sharia microfinance industry's overall results. A mechanism by which the social position of the sector can be illustrated is to provide disadvantaged entrepreneurs with microfinance (Ali 2014).

Microfinance is a movement towards providing financial services to the poor (e.g. loans, savings, insurance) who are excluded by conventional financial institutions from the scheme. At the heart of conventional banking is the belief that the poor should not be provided with credit or other financial services because of a lack of collateral. The overarching objective of microfinance is poverty reduction, although it also aims to promote education, health, gender empowerment, and improved social consciousness (Vakulabharanam and Motiram 2007). Many modern Islamic economists have recognized the absence of Justice, equity, fair care, and the satisfaction of essential needs all lead to poverty in equal measure. Islamic governance also protects the duty to eliminate poverty while ensuring justice, equality, fair treatment, and meeting basic needs (Jaffar and Musa 2014).

Islamic microfinance is at the heart of Islamic finance as it addresses one of the fundamental roles of financial intermediaries demanded by Shariah (Mansori et al., 2015). Over the past few decades, many initiatives have taken place to alleviate poverty in Muslim countries. Shariah-compliant finance can be defined as financial activities and investments that comply with Islamic law and regulations which prohibiting interest charges and involvement in any enterprise associates with any activities or products forbidden by Islamic law. Shariahcompliant finance is a factor that differentiates conventional and Islamic financial institutions (Obaidullah and Khan 2011). Therefore, Islamic microfinance must not only comply with the Shariah but to be accepted by their Muslim clients, it must be perceived to be as such. Shariah Supervisory Board (SSB) consists of distinguished scholars and experts of fiqh who would monitor and confirm that the activities or operations of the financial institutions comply with the Shariah. There are also many unresolved issues in mainstream Islamic finance that have become challenges in Islamic microfinance as well. Islamic finance refers to a financial service or product that is consistent or principally implemented to comply with the principles of Shariah or Islamic law (Gait and Worthington, 2008).

The conventional micro-financing entities are criticized (Morduch 1999, Amin, et al., 2003; Young 2010) for making high profits at the expense of the poor (Misra 2006; Vakulabharanam and Motiram 2007), and the merit of Islamic microfinance is debatable (Haji, et al., 2018a). Because of the cost of money and transactions, it is considered more costly in the Middle East and, for lack of it, cheaper in Bangladesh. Despite criticism, if it were comparatively cheaper for reasons of risk sharing, benefit-sharing, fixed rate of payment, openness, social security, and justice, Muslims would favor Islamic microfinance. (Ali 2014). The main concern is the high cost of microfinance, which is justified among others based on operational costs. 


\subsection{Islamic Countries' Poverty Status}

Poverty is twice the average for developed nations as a whole in the 56 OIC countries. Centered on the faith and values principle of debt, a variety of financial mechanisms have been developed in Southeast Asia. There are 690 million people in the total population of five major Muslim countries; Sudan, Indonesia, Bangladesh, Pakistan, and Nigeria, of which 250 million are considered living in the poverty line (Aslam 2016). In the Islamic world, mass poverty is considered to be prevalent, and many claim that this is not in line with the vast wealth of Islamic countries. This mass poverty is expressed in famine, malnutrition, disease, illiteracy, the low level and standard of poor people's consumption, and the wider reality of deprivation described above.

About 3 billion people live in poverty, 35\% of whom come from the Muslim world. The study by (Hoque, et al., 2015) states that if zakat is distributed as seed capital (investment) in the entrepreneurial system, is adequately capable of eliminating poverty in Muslim countries as well as other countries. A nation is weak, not due to a lack of capital. A sufficient number of good entrepreneurs is missing, among other items, (Mamun, et al., 2014). Empirical studies have shown that persistent absolute poverty, high unemployment, income distribution disparity, low productivity levels in the primary sector, increasing inequality of living standards, less optimal fulfillment of public facilities are the issues faced by Muslim countries (education and health), International debt is a deteriorating balance of payments, The degradation of the institutional structure and framework and mechanism of principles and customs is gradually disappearing as a result of external pressures (Rashidah and Faisal 2015).

\subsection{Poverty Status of Gambia and Efforts in Combating Poverty}

The Gambia is a small country with a population of around $2.5 \mathrm{~m}$. The people of Gambia are referred to as Gambians and the country is a 95\% Muslim nation. The Gambia's geographical distribution is therefore peculiar in its existence. Micro-credits and the supply of micro-financial services in this century have changed the lives of humans and contributed to the rebirth of various communities in the poorest and richest countries of the world so that we can see growth in human power to access loans and the Gambia is no exception. The incidence of poverty is highest in rural groundnut-producing areas. In the North Bank, Upper River, and Lower River divisions, about 65 percent of the population is poor. Many microfinance institutions in the Gambia favor women's groups because they believe they are safer and more reliable borrowers and therefore contribute to their financial viability for households.

\section{Review of Literatures}

Microfinance currently has strong potential, although somewhat ignored by conventional financial institutions, microfinance and supporting initiatives have become a priority for foreign donors, as well as governments, private companies, and philanthropic organizations (Ferro 2011). There are many reasons why microfinance could not attract financial institutions. These include microfinance's true viability, the high risk posed by small and short-term lending operations, and the common perception that due to a lack of expertise, the poor are always poor. Also, overcoming social and cultural barriers to the provision of microfinance services is extremely difficult for financial institutions, particularly in less developed countries (Ferro 2011).

Nevertheless, there is still good support from several parties for the establishment of microfinance institutions. The economic and social effect of microcredit has been studied in 
several studies and the findings have been mixed (Alawattage, et al., 2019). Afrane (2002), for example, studies the impact of two microfinance interventions in Ghana during 1997 and Semeto Microfinance Development Program (SOMED) in South Africa during 1998. The results show that microfinance programs, especially for women, lead to major increases in business incomes, access to life-enhancing facilities, and personal empowerment. Microfinance clients have enjoyed greater public respect, recognition, and self-esteem, have become more involved in community activities, and have made greater financial contributions to social initiatives (Ambe Shu et al. 2011).

\section{Research Methods}

This paper relies largely on analysis in a form of a literature review. In this the researcher uses the literature review method, to obtain data, the terms, theoretical meaning, of the data validity are determined. And these secondary data were used from studies previously performed on Islamic microfinance. The literature review was carried out after reviewing related articles, books, and other related literature (Snyder 2019). To produce the findings of the analysis, the sample was chosen for education and practice. The literature review and research literature sources are comprised of books, papers, Websites of associations, government schemes, and other organisations working on the Islamic microfinance programs. This study used the system of how to eradicate poverty in Islamic nations through an Islamic acceptable model that is attractive and more successful to compete for existing conventional microfinance development programs currently undergoing in the Gambia.

\section{Discussion}

\subsection{Financial Sector of the Gambia}

It is imperative to comprehend the structure of the financial sector of The Gambia for a better understanding of the context of the country. The financial sector of the Gambia is mainly conventional banks and microfinance institutions, the renowned microfinance institutions are, National Association of Corporative Credit Union of The Gambia (NACCUG), Reliance Financial Services Ltd, Supersonics Financial Service Ltd, and VISACA, in The Gambia, there are only one Islamic Bank and now there is two Islamic microfinance institution which is newly lunch. As a result, there is a need for Islamic microfinance in the Gambia, because the majority of the population are Muslim and the riba issue in the conventional system deprived them of taking the loan. International Islamic organizations like the Islamic Development Bank (IDB), the Islamic Financial Services Board (IFSB) should come up with initiatives to develop a global rule and policy for greater transparency and accountability in this field, as well as provide adequate support to train the management and staff of Islamic Microfinance Institutions (IMFIs) to provide better service and to assist the IMFIs in developing better services capacity. The government should also pay attention to this industry for the sustainable development of the country as well as the reduction of poverty.

When confronting this socio-economic problem, this study finds that Islamic microfinance in the form of Salaam may be an easy model to implement in The Gambia. In particular, it is hoped that the issues raised in this study will serve as a useful guidepost for the Gambia as it seeks a path to sustainable development within the global economic and social network that is likely to become increasingly significant (Weeks et al. 2021).

Traditionally, supporting Gambia's primary industries that need serious support, such as fisheries and agriculture, which are embedded in the country's economic and social system, 
and supporting diverse entrepreneurial activities, including those of women, will also strengthen the foundations of society. This also suggests that Gambian-style microfinance needs to be more socially contextualized and to relearn the principles of interaction and action of each stakeholder embedded in the community network (Jawara 2020).

Microfinance institutions can also create markets for them by buying their produce from them or connecting them to markets. More than just a financial loan to support entrepreneurship, microfinance schemes can also serve as an opportunity to educate and inspire people about social systems and the way they think and work towards a sustainable nation (Faal 2020). Based on the conclusions drawn from this study, the authors plan to develop further implications and policy recommendations on the challenges and prospects for the implementation of microfinance systems for sustainable development in The Gambia, through further research on specific cases and empirical studies based on the results and evaluation of the economic activities of microfinance-using enterprises Oe and Yamaoka (2021).

\subsection{Affordability and Defaults}

Whether a loan is affordable and readily repayable or not, the gross monthly income of the borrower needs to be considered. For affordability, the income and amount charged for repayment of the loan and other costs associated with the said loan must be looked at. If the deduction for the gross periodic repayment (loan repayment, savings, etc.) renders the creditor unable to pay to a third party the expenses of the necessaries and liabilities, so it will be inexpensive and costly in compliance with the requirements for the affordability of the loans for housing. We use this even though such a requirement is high since the applicant still needs to pay for housing and other expenses, which may force his or her monthly deductions (Haji Mohammad, et al., 2018b).

It has also been found that launching a proper Islamic micro-financing mechanism would boost the economic development of the nation as the rural population of the country would get the opportunity to become self-sufficient. Islamic micro-financing will create equal opportunity for the whole population. The expensiveness of Islamic microfinance is connected to the rate of competitors, and the earnings of the borrower. Second, sustainability cost and affordability are followed by the issue of (Haji Mohammad et al. 2018a). Findings the cost of borrowing from Islamic microfinance is represented (IsMFI). Studies in the Middle East, on the one hand, did discover that the cost of sharia microcredit is bigger than that of conventional microfinance. On the other hand, the cost of the loan looks lower, in other countries.

\subsection{Islamic Microfinance in the Gambia}

Microfinance in the Gambia could be Islamized, and there are many benefits that the population could reap from this. Gambia's microfinance potential could be expressed by listing the real reasons why the Gambia needs Islamic microfinance. $72 \%$ of citizens in Muslim countries do not use official financial services because Islam bans interest-based services, and the Gambia is no exception. For the poverty alleviation through Islamic approach, (Salleh 2017) begins with the assumption that two trade-offs are involved in poverty alleviation strategies, namely, first, between the interests of the "haves" and the "have-nots," and secondly, between the position of the public sector versus the market. When it comes back to the very worldview of Islamic teaching, the fact that life in this country, and the sense of poverty, income, and wealth disparities, is a test. Those endowed with high income and wealth by Allah Subhanahu WA TA'ALA ought to share the resources with the poor, and the 
poor, though not grudging against the wealthy, are promised to be richly rewarded in the afterlife for patiently bearing their hardship (Salleh 2017).

Islam strongly promotes the Charity department, While emphasizing the focus on believers to decrease their dependency on charity (Ariff, et al., 2012).

"The Prophet (PBUH) told in the Hadith "By Hakim ibn Hizam:" (the donor's hand) is better than the (receiver's hand). Sahị̣ al-Bukhärī1429, Saḥị̣ Muslim 1033.

Ubaidullah Ibn Adl ibn Khiyaar stated in another hadith that at the farewell pilgrimage, The Prophet (PBUH) strongly discouraged two persons from giving sadaqah (charity), but instead encouraged them to earn a living as both were capable and strong enough to work. Prophet Muhammad (PBUH) thus stressed the production of human capital and the acceleration of development in society, which fulfills the I'mar al-ard maqsad-the construction of human Beings' civilization.

Islamic MFIs have loans free of collateral and interest-free, from a theoretical point of view, unlike other conventional MFIs. As well as providing loans without interest, components of the growth of social schemes of the MFIs in compliance with sharia concentrate on components that gain directly from the weak and the vulnerable.

\subsection{The Various Islamic Micro Financing Products}

Islam submits the strategies and items of poverty assessment to the poor people accordingly. Islam has categorized the instruments of microfinance into two major groups. First, non-profit products such as Zakat, Charity, Waqaf, etc. help supply the basic needs and consumption and the initial stage for starting the micro-company. Second, to satisfy the capital requirements, the various profit-based financing methods such as Murabaha, Salam, Istisna, Ijarah, Mushrakha, and mudarbah base on the technical ability of the customer for the increasing sector. Such goods are also linked to various industries with permanent financial power (IFSB 2009).

To make these models more efficient and fruitful, it is possible to separate Islamic microfinance products into sectors that are also helpful in supporting various sectors of microfinance and preventing the misuse of resources. Ijarah has proven to be ideal for agriculture and transport, for agriculture only, which is useful for agricultural countries. For manufacturing and building, Istisna has proved to be useful. Important for petty trade, shopkeeping, transport, street hawkers, and livestock, Murabaha. In terms of assets, transportation, and development, diminishing musharkah can be used for microentrepreneurs. For livestock, micro-trade, and transportation, Musharkah proved to be helpful.

The biggest challenges facing the global development community as the world has already passed into the new millennium are attacking chronic poverty and resolving low levels of social and economic development of Muslims worldwide. The war is far from won, amid progress over the last three decades, seeing a revolution in providing finance to alleviate poverty across the globe. As a result, the issue of financial inclusion has arisen as a policy issue primarily to ensure the availability of credit to small and medium-sized enterprises that are generally denied access to mainstream financial institutions and consumer credit. (Wajdi Dusuki 2008). 


\subsection{Suitable Islamic Microfinance Models for the Gambia}

Islamic Microfinance, an Islamic alternative to traditional interest-based loans is partner-based, commercial-based, or lease-based loans that allow the ownership and/or use of the goods or physical assets necessary for productive enterprises. Centered on the MF Relationship, it works on profit and loss sharing and there is a reciprocal arrangement between micro and financial entrepreneurs. In this group, business contracts include mudaraba, musharka, and decreasing musharka. Poor Muslim micro-entrepreneurs need and seek access to financial services that do not compromise their Riba, Maysir, and Gharar religious beliefs. The Islamic Micro Finance System focuses on the establishment of infrastructure and trade at Halal, which is beneficial to the Society.

Mudarabah: is an Arabic word meaning a company (project) in which one party (a company or person) provides capital while the other party contributes effort and abilities (beneficiary, entrepreneur, or borrower). The owner of financial resources is referred to as "rabble-mal" and "Mudarib" is the partner with entrepreneurial skills. The profit-sharing ratio is negotiated between the parties for the validity of Mudarabah, at the beginning of the contract. Profit-sharing must be proportionate, and either the capital owner (Rabb-ul-Mal) or the Mudarib should not be assigned a "Lump sum" number. The capital owner will lose his capital in the event of a complete loss and "Mudarib" will lose his future gain from profit. Islamic Micro-Finance: Mudarabah The bank provides the capital available for a microenterprise under a Mudarabah contract, while the micro-entrepreneur offers labor and expertise. Profits (or losses) from such funding are shared at a set ratio between the bank and the entrepreneur.

Musyarakah: Musyarakah is a form of partnership between two or more persons in the form of revenue sharing, with the distribution of income. For a particular company, it can be described as a cooperation agreement between two or more parties, in which the provisions separated by the agreement are contributed by each member, while partners together provide funds to finance a specific business in the region, both current and new. Investments in Musyarakah may be in the form of capital, cash equivalents, or non-cash properties.

Murabahah: Murabahah is a sale and purchase transaction where the amount of profit gained is specified by the bank. Although the consumer is the buyer, the bank functions as the seller. The sale price is the supplier's purchasing price of the bank, plus the benefit (margin). Murabahah is a particular type of selling and purchase in figh terms where the seller specifies the cost of procurement of products (al-tsaman al-awwal) and the desired amount of benefit. Murabahah falls under the category of trading in muthlaq and mandate trading. It is called muthlaq trading, as goods and money are the objects of the deal. The purpose of this model will be two-fold: to support the poor and to obtain some financial benefit from the system. There are certainly several Islamic mechanisms used to accomplish this purpose. However, it is the view of the author that Islamic microfinance in the form of Salam could be the most acceptable type of Islamic contract that could be used in the Gambia. To support the Gambia's declining industries that need serious assistance, such as women entrepreneurs, the fishing industry, and agriculture. To grow and maintain these industries, the Salam contract will thus work like a miracle.

Islam believes that even if people were given the same opportunities, each person would not have the same level of economic status. That is because, in terms of their desire to achieve a certain degree of economic status, people are different (Hassan 2010). Thus, Islam sees it as part of social justice and confidence in Allah to eradicate poverty. One of Islam's pillars is paying zakat, which means purifying one's riches for the will of Allah; understanding 
that Allah belongs to everything we own, and working for the improvement of the Muslim Ummah (i.e. community or society). It is not only obligatory for every Muslim who can afford to pay zakat but it is a form of worship to Allah by sharing the wealth with the less fortunate. Poverty cannot, however, be alleviated solely by redistribution of income and equal opportunities, but it requires a systemic solution that is a mixture of poverty alleviation policies in Islam, including a rise in income levels biased towards improving the disadvantaged population, creating an egalitarian framework for the distribution of wealth and eventually ensuring that all classes of society are equal opportunities (Abu Umar and Habib 2013). All these are some of the methods that microfinance institutions can follow in the Gambia to eradicate poverty, especially in women and the poor in general.

\subsection{Why Does the Current Model not Work Adequately to Alleviate Poverty?}

There are different explanations why, as it was reported, the existing microfinance program does not eliminate poverty in the Gambia, the reasons why current and conventional models do not function correctly and are unable to reduced poverty are as follows.

"The main reason is Riba is prohibited, as stated in the Quran "Allah kills riba and nurtures charitable organizations," and in another hadith, "In every society, when Riba becomes prevalent, It leads to starvation and poverty, the financial system based on riba does not help a real change in life but instead keeps businesses making a profit.

The poor clients should not avail themselves of their loans for other purposes different from a business that could change their lives. They use them for reasons that are not productive, such as furnishing rooms, handing them over to other family members, marriage, social ceremonies, etc. There is no right way out to determine the precise level of poverty that results do not adequately serve the need as needed.

Currently, all Gambia's microfinance institutions are traditional and function on an interest-based basis, especially the Women's Finance Study Program, which covers the whole of Gambia and is part of the Women's Finance Study Program across the Gambia. And because the Gambia is a Muslim country, Islamic microfinance is gaining momentum in the world and is believed to be the right instrument to eradicate poverty rather than the usual conventional approach, which is relevant for these institutions to consider adopting it.

\subsection{Prohibition of Riba in Islam}

The word "Riba" is an Arabic meaning According to Shariah terminology, surplus, increase or extension, is correctly interpreted and means any excess reward without consideration. Quran says (Kaleem and Ahmed 2010).

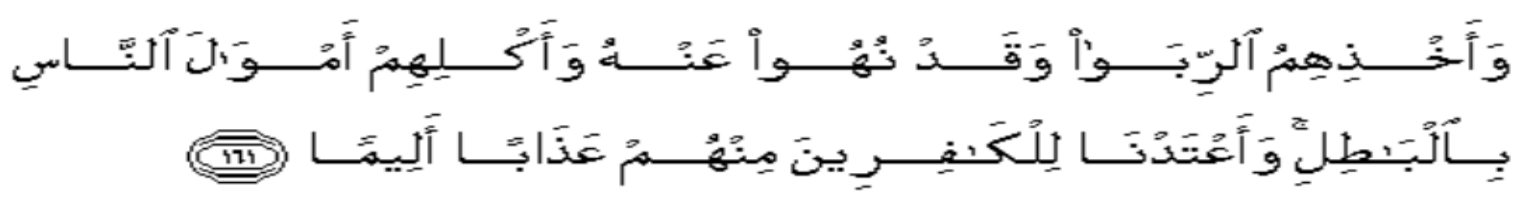


And their taking of riba though they were forbidden from it and their devouring of men's wealth wrongfully. And we have prepared for those among them who reject faith a painful punishment.

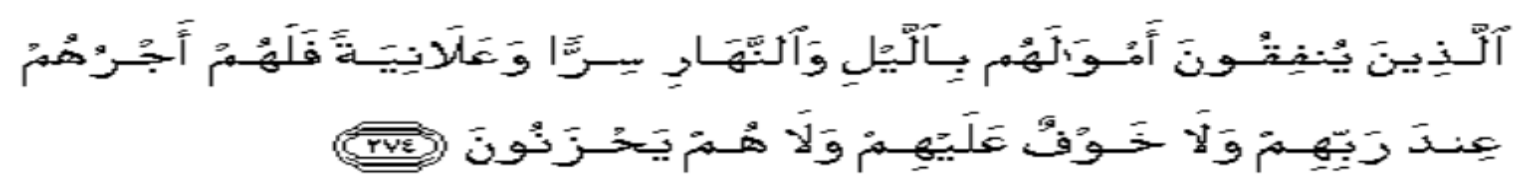

2:274 those who spend of their wealth (in charity) by night and by day, in secret and in public, have their reward with their Lord: on them shall be no fear, nor shall they grieve.

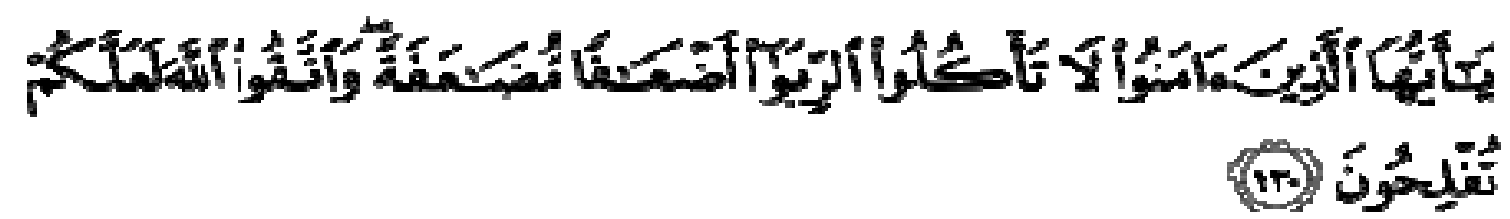

"O you who have believed, do not consume usury, doubled and multiplied, but fear Allah that you may be successful" Islam introduces its model of poverty reduction, which is popular in the Islamic world according to shariah.

\section{Conclusion}

Microfinance programmers that were introduced in the Gambia for decades still could not reduce poverty in the smallest country in West Africa with a population of less than $3 \mathrm{~m}$, further consideration is needed for poverty alleviation, to achieved the objective of offering a better standard of life. More than 65 percent of the population are still under the poverty line, and many do not have access to healthcare, electricity, safe and clean drinking water, and basic nutrition. These issues are exacerbated by the current political and economic turmoil.

However, this research finds out that major reasons behind the slow rate or failure of existing microfinance program to eradicate poverty include: Riba is prohibited, affordability of the loans, the income and amount charged for repayment of the loan and other costs associated with the said loan must be looked at, the diversions of loan for different purposes other than business, effects of the high-interest rate of the credits taken from the conventional MFIs, deprivation from the rights of human development. Islamic MFIs have loans free of collateral and interest-free, from a theoretical point of view, unlike other conventional MFIs. As well as providing loans without interest, components of the growth of social schemes of the MFIs in compliance with sharia concentrate on components that gain directly from the weak and the vulnerable. First, non-profit products such as Zakat, Charity, Waqaf, etc. Second, to satisfy the capital requirements, the various profit-based financing methods such as Murabaha, Salam, Istisna, Ijarah, Mushrakha, and mudarbah.

Empirical studies have shown that persistent absolute poverty, high unemployment, income distribution disparity, low productivity levels in the primary sector. However, it is the view of the author that Islamic microfinance in the form of Salam could be the most acceptable type of Islamic contract that could be used in the Gambia. To support the Gambia's declining industries that need serious assistance, such as women entrepreneurs, the fishing industry, and agriculture. To grow and maintain these industries, the Salam contract will thus work like a miracle. Islamic MFIs have loans free of collateral and interest-free, from a theoretical point of view, unlike other conventional MFIs. As well as providing loans 
without interest, components of the growth of social schemes of the MFIs in compliance with sharia concentrate on components that gain directly from the weak and the vulnerable.

Therefore, it will be more effective to create jobs instead of providing cash loans to people who have no knowledge or skills to do business. Jobs could be created based on local experiences which have already proven to be successful in the country, and hence would minimize the risk of unwanted loss. For example, in my communities, women and poor farmers too have landed but lack the means and facilities to make maximum utilization of those resources to change their lives, with Islamic microfinance they can provide finance for them have irrigation facilities all year-round farming, to improve their production and in that poverty can be reduced using the various Islamic microfinance tools mentioned above. And the microfinance institution can also create a market for them in a form of buying them produces from them or link them to the markets.

A future research goal is to evaluate the results of this study through a detailed survey that considers the respondents' attributes. However, as a pilot test in many countries indicate that Islamic microfinance is an applicable and more favorable tool for poverty eradication, this study indicates that women and farmers, with entrepreneurial spirit, could use various loan products of Islamic microfinance. And they may be prepared to take a stand for the sustainable development of their local communities. However, we are well aware that the results obtained here require further in-depth study and validation before generalizing.

\section{References}

Abu Umar, Faruq Ahmad and Farrukh Habib. 2013. "Role of Zakah in Poverty Alleviation through Redistributive Justice." Proceedings of World Universities' Islamic Philanthropic 2013 (October): 26.

Afrane, Sam. 2002. "Impact Assessment of Microfinance Interventions in Ghana and South Africa: A Synthesis of Major Impacts and Lessons." Journal of Microfinance / ESR Review 4(1):4.

Al-mubarak, Tawfique. n.d. "Going 'Beyond Microfinance': Enhancing Islamic.” (iii).

Alawattage, Chandana, Cameron Graham, and Danture Wickramasinghe. 2019. "Microaccountability and Biopolitics: Microfinance in a Sri Lankan Village." Accounting, Organizations and Society 72:38-60.

Ambe Shu, Cletus, Bilge Oney, Beatriz Armendáriz de Aghion, Jonathan Morduch, Helms Bright, 2011. "Measuring Results of Microfinance Institutions Minimum Indicators That Donors and Investors Should Trac.Pdf." University of Birmingham Research Archive E-Theses Repository 4(1):1-11.

Amin, Sajeda, Ashok S. Rai, and Giorgio Topa. 2003. "Does Microcredit Reach the Poor and Vulnerable? Evidence from Northern Bangladesh." Journal of Development Economics 70(1):59-82.

Ariff, Mohamed, Meysam Safari, and Shamsher Mohamad. 2012. Sukuk Securities, Their Definitions, Classification and Pricing Issues Mohamed Ariff, Meysam Safari And.

Aslam, Muhammad Naveed. 2016. "Islamic Microfinance Model to Reduce Poverty: Pakistan's Case." International Journal of Management Sciences and Business Research 5(8):1-9.

Faal, Musa L. 2020. "Understanding Binding Constraints to Small and Medium Enterprises (SMEs ) in The Gambia : A Critical Review." 11(02):216-21. 
Fatoni, Ahlis, Sebastian Herman, and Adam Abdullah. 2019. "Ibn Khaldun Model on Poverty: The Case of Organization of Islamic Conference (Oic) Countries." Journal of Islamic Monetary Economics and Finance 5(2):341-66.

Ferro, Nicoletta. 2011. "Value Through Diversity: Microfinance and Islamic Finance and Global Banking." SSRN Electronic Journal (I).

Gertler, Paul, David I. Levine, and Enrico Moretti. 2009. "Do Microfinance Programs Help Families Insure Consumption against Illness?” Health Economics 18(3):257-73.

Haji Mohammad, Mohammad Tahir Sabit, David Martin@. Daud Juanil, and Sabariah Eni. 2018a. "Affordability of Islamic Microfinance." Journal of Technology Management and Business 5(3).

Haji Mohammad, Mohammad Tahir Sabit, David Martin@. Daud Juanil, and Sabariah Eni. 2018b. "Affordability of Islamic Microfinance." Journal of Technology Management and Business 5(3):43-53.

Hassan, M. Kabair. 2010. “An Integrated Poverty Alleviation Model Combining Zakat, Awqaf and Micro-Finance. Seventh International Conference - The Tawhidi Epistemology: Zakat and Waqf Economy, Bangi 2010." Seventh International Conference - The Tawhidi Epistemology: Zakat and Waqf Economy, Bangi 2010 AN (January):261-81.

Hassan, Salwana, Rashidah Abdul Rahman, Nordin Abu Bakar, Rohani Mohd, and Aliyu Dahiru Muhammad. 2013. "Designing Islamic Microfinance Products for Islamic Banks in Malaysia." Middle East Journal of Scientific Research 17(3):359-66.

Hoque, Nazamul, Mohammad Aktaruzzaman Khan, and Kazi Deen Mohammad. 2015. "Poverty Alleviation by Zakah in a Transitional Economy: A Small Business Entrepreneurial Framework." Journal of Global Entrepreneurship Research 5(1).

Hoque, Nazamul, Abdullahil Mamun, and Abdullah Mohammad Ahshanul Mamun. 2014. "Dynamics and Traits of Entrepreneurship: An Islamic Approach." World Journal of Entrepreneurship, Management and Sustainable Development 10(2):128-42.

IFSB. 2009. "Islamic Microfinance Report." "International Technical and Economical CoOperation" Faculty of Business Administration Islamic Microfinance (February):1-30.

Jaffar, Mariatul Aida and Rosidah Musa. 2014. "Determinants of Attitude towards Islamic Financing among Halal-Certified Micro and SMEs: A Preliminary Investigation." Procedia - Social and Behavioral Sciences 130:135-44.

Jawara, Hamidou. 2020. "Access to Savings and Household Welfare Evidence from a Household Survey in The Gambia." African Development Review 32(2):138-49.

Kaleem, Ahmad and Saima Ahmed. 2010. "The Quran and Poverty Alleviation: A Theoretical Model for Charity-Based Islamic Microfinance Institutions (MFIS)." Nonprofit and Voluntary Sector Quarterly 39(3):409-28.

Khalifa Mohamed Ali. 2014. "Integrating Zakah, Awqaf and IMF for Poverty Alleviation: Three Models of Islamic Micro Finance.”' Irti 2(3):193-211.

Khan, Tariqullah, Development Bank, and Management Sciences. 2010. "BOOK REVIEW ISLAMIC MICRO FINANCE DEVELOPMENT:” 1(1):121-25.

Mansori, Shaheen, Chin Sze Kim, and Meysam Safari. 2015. "A Shariah Perspective Review on Islamic Microfinance." Asian Social Science 11(9):273-80.

Misra, Alok. 2006. "Micro Finance in India and Millennium Development Goals: Maximising Impact on Poverty." World Bank Annual Meeting Workshop Singapore 1-20.

Morduch, Jonathan. 1999. "The Role of Subsidies in Microfinance: Evidence from the Grameen Bank.” Journal of Development Economics 60(1):229-48.

Obaidullah, Mohammed and Tariqullah Khan. 2011. Islamic Microfinance Development: Challenges and Initiatives. 
Oe, H. and Yamaoka, Y. 2020. How to enhance sustainability goals implementation in business behaviour: A lesson from discussions with Japanese small and medium-sized enterprises. Social Business, 10(3), 281-304.

Park, Albert and Changqing Ren. 2001. "Microfinance with Chinese Characteristics." World Development 29(1):39-62.

Rashidah, Abdul Rahman and Dean Faisal. 2015. "Humanomics Article Information:" Humanomics 31(3):354-71.

Salleh, Muhammad Syukri. 2017. "Contemporary Vision of Poverty and Islamic Strategy for Poverty Alleviation." SAGE Open 7(2).

Snyder, Hannah. 2019. "Literature Review as a Research Methodology: An Overview and Guidelines.” Journal of Business Research 104(March):333-39.

Union, European. 2019. “Women' s Economic Empowerment in The Gambia PoWER Assessment of." (June).

Vakulabharanam, Vamsi and Sripad Motiram. 2007. "The Ethics of Microfinance and Cooperation.” Éthique et Économique / Ethics and Economics 5(2003):1-10.

Wajdi Dusuki, Asyraf. 2008. "Banking for the Poor: The Role of Islamic Banking in Microfinance Initiatives." Humanomics 24(1):49-66.

Weeks, Max, Hiroko Oe, Yasuyuki Yamaoka, and Takuya Hirata. 2021. "Young Businesspeople's Entrepreneurial Perceptions and Intentions to Contribute to Local Communities: A Case Study of the Cultured Pearl Industry in Mie, Japan." Economit Journal: Scientific Journal of Accountancy, Management and Finance 1(2):96-109.

Yaqub, J. O. and H. T. Bello. 2011. "Applicability of Chapra' S Model of Islamic Banking in Nigeria." European Scientific Journal 8(15):72-85.

Young, Stephen. 2010. “The 'Moral Hazards' of Microfinance: Restructuring Rural Credit in India." Antipode 42(1):201-23. 